\title{
ANALYSIS OF PRESCRIPTION AND CONSUMPTION OF MEDICINES IN CHILDREN AND ADOLESCENTS
}

\author{
Lehocká, L.-Fulmeková, M.-Masaryková L. \\ Comenius University in Bratislava, Faculty of Pharmacy, Department of Organization \\ and Management in Pharmacy, \\ University Pharmacy, Faculty of Pharmacy, Comenius University, Bratislava
}

\begin{abstract}
In our study we analysed the prescription and consumption of medicines in children and adolescents. A total of 5200 medical prescriptions realized by a community pharmacy were evaluated. By selection of medical prescriptions prescribed to patients in the age group of up to 18 years of age a study group of 233 prescriptions was made. The group was identified by age and sex of the patients. In the group of prescriptions we analysed the incidence of individual diagnoses and consumption of medicines from different points of view, according to age, sex and rate of individual diagnoses according to the ATC system. Based on our analysis it was concluded, that the most frequent diseases affecting children and adolescents are diseases of the respiratory system, diseases of the ear and mastoid process, digestive system and skin diseases. With the exception of diseases of the skin and subcutaneous tissue, the incidence of all diseases is quite similar in both sexes. In the present, the consumption of prescription medicines used by children and adolescents is still very high mainly in the age group from 7 to 15 years of age.
\end{abstract}

Keywords: morbidity of children and adolescents - incidence of diagnoses in childrenconsumption of medicines in children-prescription of medicines in children

\section{INTRODUCTION}

The Slovak republic belongs among younger states of Europe not only by its own existence, but according to the Statistical institute of Slovakia the population of inhabitants up to 18 years of age was 1103452 in 2010 , which is $20.3 \%$ of the overall population (in 2000 it was $27.3 \%$ ). If we speak about children in Slovakia, it concerns roughly one fifth of the population.

Chronic and acute morbidity of children increased in the last 20 years and reached $30 \%$. Number of patients suffering from hypertension increased 8 times, from diabetes 5 times and from psychological disorders by $50 \%$. Incidence of allergic rhinitis and asthma rose 5 times in the last 10 years, incidence of atopic eczema rose statistically 
relevantly, chronic respiratory diseases rose 6.4 times to $7.7 \%$ in the last 20 years. Diseases of the musculo-skeletal system represented $2.1-3.1 \%$, sight disorders around $6 \%[1]$.

Rate of individual diseases in children population determines and influences use of medicines in children. Increased incidence of diseases influences drug consumption of various groups of the ATC system.

Monitoring the morbidity and health status of children is inevitable for guaranteeing health care in this age category. Research advances in health science make possible to develop prevention and use of prophylactic measures in active improvement of health status of children population [2, 3].

\section{METHODS}

In our study we studied and evaluated the consumption of medicines in children and adolescents. We analysed medical prescriptions (MP) dispensed in the public pharmacy chosen on a random basis in the period of March - November 2009. From the overall study group made up of 5200 prescriptions we first selected those prescribed to patients born in the time period 1991 - 2009. The selected prescriptions formed a narrower study group consisting of patients up to (and including) 18 years of age, which was further processed. The crude data were provided in a form of an MS Excel sheet. Source data consisted of the following: Date of Birth, sex, code of diagnosis, drug name and the number of prescribed packages.

\section{RESULTS AND DISCUSSION}

In the overall study group made up of 5200 medical prescriptions (MP) there were 233 prescriptions prescribed for patients born between $1991-2009$ (patients up to 18 years of age, included e. g. children and adolescents), which represents $4.48 \%$ of the total study group. The analysed 233 medical prescriptions contained altogether 366 packages of medicines prescribed, which means 1.5 packages for 1 prescription on average. The study group of 233 medical prescriptions consisted of 115 kinds of medicines.

Figure 1 describes the study group according to age of patients expressed by number of medical prescriptions related to age of patients. The greatest number of MPs -29 (e.g.12.5\%) was prescribed for 4-year-old children, followed by 2- and 5-year old children - 19 (e.g. 8.15\%). 


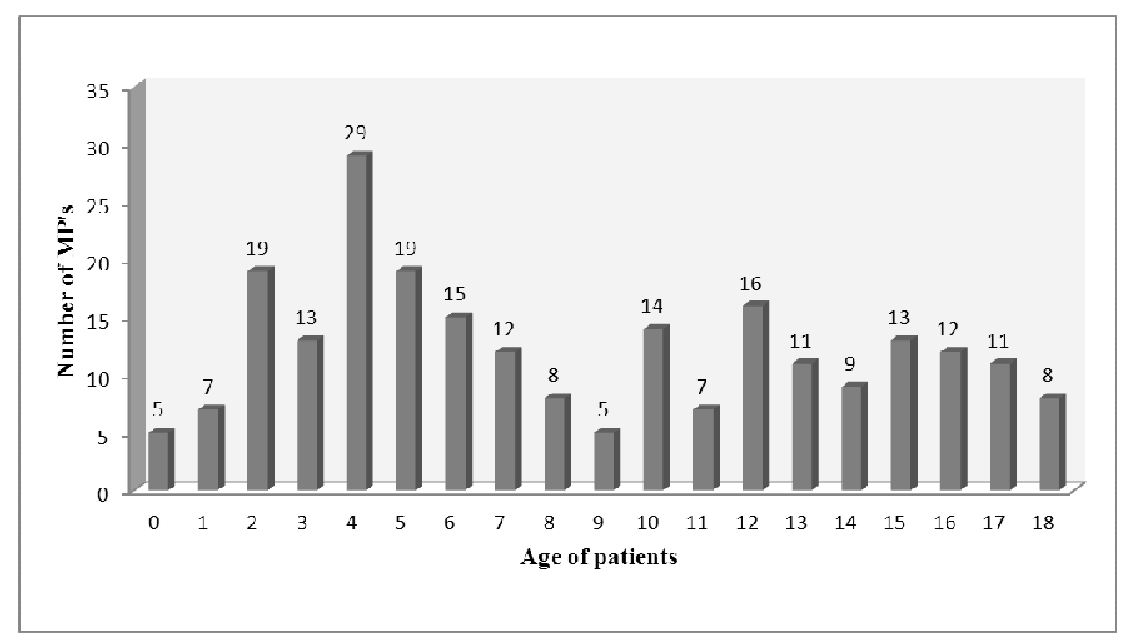

Figure 1. Distribution of group of patients according to age and number of medical prescriptions

For better characteristic and assessment of the number of medical prescriptions (MPs) we divided the group into 4 subgroups according to age (Fig. 2). For patients of the age group 0-3 years of age there were 44 MPs prescribed (e.g.18.9\%), in group 4-6 years of age it was 63 MPs (e.g.27.0\%), in group 16-18 years of age 31 MPs (e.g. $13.3 \%$ ). In the age group 7-15 years of age there were recorded the highest number of MPs - 95 (e.g. $40.8 \%$ ), which was caused by the highest number of age groups represented.

We found that the representation of both sexes was quite evenly distributed. Girls had 116 MPs (e.g. 49.8\%), and boys had 117 MPs (e.g. 50.2\%) prescribed to them, respectively. In the analyzed group there were 60 different types of diagnoses prescribed, mainly from groups $\mathrm{J}, \mathrm{H}, \mathrm{K}, \mathrm{L}$ and others. In the study group, these diagnoses occurred 266 times. They were predominantly from the following groups: "J"- Diseases of the respiratory system (J00-J06), "H" - Diseases of the ear and mastoid process (H60-H95), "K"- Diseases of the digestive system(K00-K93), "L" Diseases of the skin and subcutaneous tissue (L00-L99), and others.

In incidence of diagnoses the first place belonged to group „J“, which was represented by 17 various diagnoses occurring 179 times (e.g. $67.3 \%$ ). The second was the group „L“, which was represented by 12 various diagnoses and occurred 30 -times (e.g. 11.3\%) and the third was group „H“ represented by 8 types of diagnoses occurring altogether24 times (e.g.9.0\%) (Fig. 4). 
Figure 4. Distribution of group of prescriptions according to incidence of diagnoses

Regarding the evaluation of the group according to age of the patients, the highest number of medical prescriptions was written in the age group of 7-15-year-old children. This group consisted of the highest number of children and the important factor was the mandatory school attendance. Comparable in results of prescription rate was the age group of 4-6 years old children, where the consumption of medicines was in the three years almost the same for ATC group „J“', as in the group of 7-15-year- old children, 84 packages - (e.g. 34.6\%). This data show considerably high morbidity of preschool age children. Number of packages prescribed for diagnosis "J" and other diagnoses was rather evenly distributed from sex of patients point of view (it means that there was comparable incidence of diseases of respiratory system in both sexes). In "J" diagnosis girls had 127 packages (e.g. 52.3\%), while boys had 116 packages (e.g. 47.7\%) prescribed (Tab. 1). The most common diagnosis was J01 acute sinusitis. The most frequently prescribed drugs for diagnoses „J“ were PAMYCON, RIBOMUNYL and FLONIDAN.

Table 1. Number of prescribed packages of drugs for Dg. „J“ according to age and sex

\begin{tabular}{|c|c|c|c|c|c|c|}
\hline $\begin{array}{l}\text { Age } \\
\text { groups } \\
\text { [years] }\end{array}$ & $\begin{array}{l}\text { Number } \\
\text { of packages } \\
\text { boys }\end{array}$ & {$[\%$ \%] } & $\begin{array}{l}\text { Number } \\
\text { of packages } \\
\text { girls }\end{array}$ & {$[\%]$} & $\begin{array}{l}\text { Total } \\
\text { number of } \\
\text { packages }\end{array}$ & {$[\%]$} \\
\hline $\mathbf{0 - 3}$ & 15 & 6.2 & 23 & 9.5 & 38 & 15.6 \\
\hline $\mathbf{4 - 6}$ & 42 & 17.3 & 42 & 17.3 & 84 & 34.6 \\
\hline $\mathbf{7 - 1 5}$ & 43 & 17.7 & 45 & 18.5 & 88 & 36.2 \\
\hline $\mathbf{1 6}-\mathbf{1 8}$ & 16 & 6.6 & 17 & 7.0 & 33 & 13.6 \\
\hline Total & 116 & 47.7 & 127 & 52.3 & 243 & 100.0 \\
\hline
\end{tabular}


Number of packages in diagnosis „ „H“ showed more frequent incidence of diseases of the ear in girls with 21 prescribed packages (e.g.60.0\%), while in boys it was 14 packages (e.g. 40.0\%) (Tab. 2). The most frequently prescribed drugs for diagnoses „,H“ were PAMYCON, OPHTALMO-FRAMYCOIN and ZINNAT. Diseases of gastrointestinal system also affected girls more than boys.

Table 2. Number of prescribed packages of drugs for Dg. „H“ according to age and sex

\begin{tabular}{|c|c|c|c|c|c|c|}
\hline $\begin{array}{l}\text { Age } \\
\text { group } \\
\text { [years] }\end{array}$ & $\begin{array}{l}\text { Number } \\
\text { of package } \\
\text { s boys }\end{array}$ & {$[\%]$} & $\begin{array}{l}\text { Number } \\
\text { of package } \\
\text { s girls }\end{array}$ & {$[\%]$} & $\begin{array}{l}\text { Total } \\
\text { number } \\
\text { of packages }\end{array}$ & {$[\%]$} \\
\hline $\mathbf{0}-\mathbf{3}$ & 2 & 5.7 & 3 & 8.6 & 5 & 14.3 \\
\hline $\mathbf{4 - 6}$ & 4 & 11.4 & 5 & 14.3 & 9 & 25.7 \\
\hline $\mathbf{7 - 1 5}$ & 8 & 22.9 & 9 & 25.7 & 17 & 48.6 \\
\hline $\mathbf{1 6}-\mathbf{1 8}$ & 0 & 0.0 & 4 & 11.4 & 4 & 11.4 \\
\hline Total & 14 & 40.0 & 21 & 60.0 & 35 & 100.0 \\
\hline
\end{tabular}

Diagnosis „, $\mathrm{K}^{\prime}$ included 12 packages prescribed in girls (e.g. 63.2\%), while in boys only 7 packages (e.g. 36.8\%) (Tab. 3).The most frequently prescribed drugs for diagnoses „K“ “ were NUTRILON 2 AR, HYLAK FORTE GTT and SMECTA.

Table 3. Number of prescribed packages of drugs for $\mathrm{Dg}$. „,K“ according to age and sex

\begin{tabular}{|c|c|c|c|c|c|c|}
\hline $\begin{array}{l}\text { Age } \\
\text { group } \\
\text { [years] }\end{array}$ & $\begin{array}{l}\text { Number } \\
\text { of packages } \\
\text { boys }\end{array}$ & {$[\%]$} & $\begin{array}{l}\text { Number } \\
\text { of packages } \\
\text { girls }\end{array}$ & {$[\%]$} & $\begin{array}{l}\text { Total } \\
\text { number } \\
\text { of packages }\end{array}$ & {$[\%]$} \\
\hline $\mathbf{0}-\mathbf{3}$ & 2 & 10.5 & 8 & 42.1 & 10 & 52.6 \\
\hline $\mathbf{4 - 6}$ & 0 & 0.0 & 2 & 10.5 & 2 & 10.5 \\
\hline $\mathbf{7 - 1 5}$ & 4 & 21.1 & 1 & 5.3 & 5 & 26.4 \\
\hline $\mathbf{1 6}-\mathbf{1 8}$ & 1 & 5.3 & 1 & 5.3 & 2 & 10.5 \\
\hline Total & 7 & 36.8 & 12 & 63.2 & 19 & 100.0 \\
\hline
\end{tabular}

We observed bigger differences in prescription rates according to the sex of patients in diagnosis „L“, where girls had 13 packages (e.g. $34.2 \%$ ), and boys 25 packages prescribed (e.g. 65.8\%), which corresponds with greater susceptibility to skin diseases in boys (Tab.4). The most frequently prescribed drugs for diagnoses „L" were CLARITINE, BACTROBAN and FENISTIL. 
Table 4. Number of prescribed packages of drugs for Dg. „L“ according to age and sex

\begin{tabular}{|c|c|c|c|c|c|c|}
\hline $\begin{array}{l}\text { Age group } \\
\text { [years] }\end{array}$ & $\begin{array}{l}\text { Number } \\
\text { of packages } \\
\text { boys }\end{array}$ & {$[\%]$} & $\begin{array}{l}\text { Number } \\
\text { of packages } \\
\text { girls }\end{array}$ & {$[\%]$} & $\begin{array}{l}\text { Total number } \\
\text { of packages }\end{array}$ & {$[\%]$} \\
\hline $\mathbf{0 - 3}$ & 4 & 10.5 & 1 & 2.6 & 5 & 13.2 \\
\hline $\mathbf{4 - 6}$ & 1 & 2.6 & 1 & 2.6 & 2 & 5.3 \\
\hline $\mathbf{7 - 1 5}$ & 15 & 39.5 & 9 & 23.7 & 24 & 63.2 \\
\hline $\mathbf{1 6}-\mathbf{1 8}$ & 5 & 13.2 & 2 & 5.3 & 7 & 18.4 \\
\hline Total & 25 & 65.8 & 13 & 34.2 & 38 & 100.0 \\
\hline
\end{tabular}

In other diagnoses there were 17 packages prescribed to girls (e.g. 54.8\%), and 14 in boys (e.g. $45.2 \%$ ) (Tab. 5). The most frequently prescribed drugs for other diagnoses were NAPSYN, RIBOMUNYL and BEBA.

Table 5. Number of prescribed packages of drugs for other Dg. according to age and sex

\begin{tabular}{|c|c|c|c|c|c|c|}
\hline $\begin{array}{l}\text { Age group } \\
\text { [years] }\end{array}$ & $\begin{array}{l}\text { Number } \\
\text { of packages } \\
\text { boys }\end{array}$ & $\mathbf{[ \% ]}$ & $\begin{array}{l}\text { Number } \\
\text { of packages } \\
\text { girls }\end{array}$ & {$[\%]$} & $\begin{array}{l}\text { Total number } \\
\text { of packages }\end{array}$ & {$[\%]$} \\
\hline $\mathbf{0 - 3}$ & 6 & 19.4 & 2 & 6.5 & 8 & 25.8 \\
\hline $\mathbf{4 - 6}$ & 1 & 3.2 & 4 & 12.9 & 5 & 16.1 \\
\hline $\mathbf{7 - 1 5}$ & 6 & 19.4 & 8 & 25.8 & 14 & 45.2 \\
\hline $\mathbf{1 6}-\mathbf{1 8}$ & 1 & 3.2 & 3 & 9.7 & 4 & 12.9 \\
\hline Total & 14 & 45.2 & 17 & 54.8 & 31 & 100.0 \\
\hline
\end{tabular}

An overall review on drug consumption according to the ATC system is in Figure 5. It shows that the greatest drug consumption was in group „R“ (Respiratory system) of the ATC system expressed by number of packages - 111 (e.g. 30.3\%), followed by group „J“ (Antiinfectives for systemic use) with 86 packages (e.g. 23.5\%). The third was the group „D“(Dermatologicals)with 58 packages (e.g. 15.8\%). The least drug consumption was in group "V" where there was just 1 drug prescribed (e.g. 0.3\%) [4-7]. 


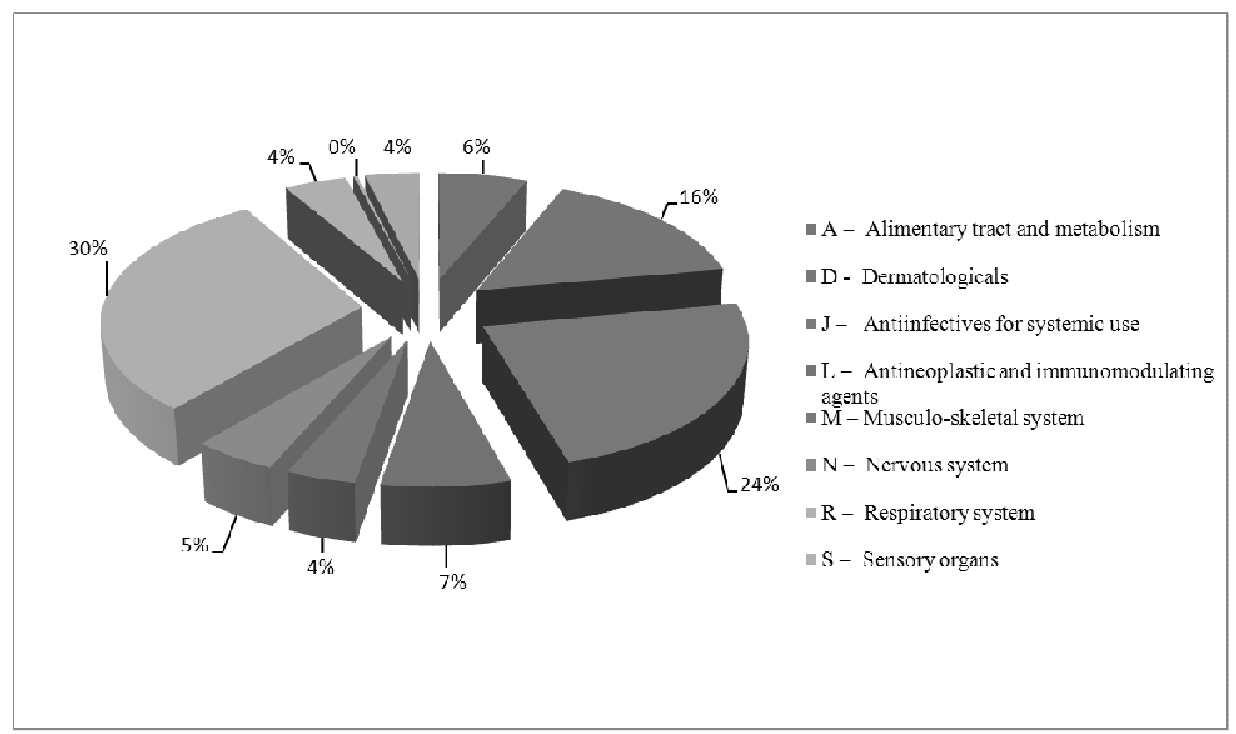

Figure 5. Analysis of consumption of medicines according to ATC system

\section{CONCLUSION}

Morbidity and subsequent pharmacotherapy screening in children and adolescents are essential for monitoring their health status and assuring the best healthcare for this age group of patients. Diseases of children and their treatment are markedly different form that in adults. A child is more vulnerable and susceptible to various types of pathogens and allergens. According to our research the most common diseases of children and adolescents are diseases of the respiratory system, diseases of the ear and mastoid process, diseases of the digestive system and diseases of the skin and subcutaneous tissue. With the exception of diseases of the skin and subcutaneous tissue, the incidence of all diseases is quite similar in both sexes. We can conclude that the consumption of prescription medicines used by children and adolescents is still very high mainly in the age group from 7 to 15 years of age.

\section{REFERENCES}

1. BAKOŠOVÁ, Z. et al.: Needs, conditions and perspectives of children and adolescents in Slovakia, Foundation for children of Slovakia, Bratislava, 2003, 94p.

2. KLIEGMAN. - R.M.: Nelson Textbook of Paediatrics $19^{\text {th }}$ edition, W.B. Saunders Company, 2010, ISBN: 1437707556.

3. ŠAŠINKA, M. - ŠAGÁT, T. - KOVÁCS, L. et al.: Paediatrics, Herba, Bratislava, 2007, ISBN: 8089171491, 1450p. in Slovak

4. LÜLLMANN, H. - MOHR, K. - ZIEGLER, A.: Pharmacology and toxicology, Grada, Praha, 2004, ISBN 80-247-0836-1, 728 p.in Slovak 
5. VLČEK, J. - FIALOVÁ, D. - KULIČ, F.et al.: Clinical pharmacy I, Grada, Praha, 2010, ISBN 978-80-247-3169-8, p.368. in Czech

6. BRAND, P.L.P. - BARALDI, H. - BISGAARD, H. et al.: Definition, assessment, disorders in preschool children: an evidence - based approach, Eur. Respir. J., 2008, 32, p.196-1110.

7. GUNASEKERA, H. - MORRIS, P.S. - MCINTYRE, P. - CRAIG J.C.: Management of children with otitis media: A summary of evidence from recent systematic reviews, Journal of Paediatrics and Child Health, 2009, 45(10), p. 554-563.

Registered: February,2012

Accepted: March2012

PharmDr. Lubica Lehocká, PhD.

Faculty of Pharmacy

Comenius University

Odbojárov 10

83232 Bratislava

lehocka@fpharm.uniba.sk

\section{ANALÝZA PRESKRIPCIE A SPOTREBY LIEKOV U DETÍ A MLÁDEŽE}

Lehocká, L. - Fulmeková, M. - Masaryková, L.

Univerzita Komenského v Bratislave, Farmaceutická fakulta, Katedra organizácie a riadenia farmácie,

Univerzita Komenského v Bratislave, Farmaceutická fakulta, Univerzitná lekáreň

Práca sa zaoberala analýzou preskripcie a spotreby liekov u detí a dospievajúcej mládeže. Celkovo bolo spracovaných 5200 receptov realizovaných verejnou lekárňou. Vyčlenením lekárskych predpisov pre pacientov do 18 rokov sa vytvoril analyzovaný súbor, ktorý tvoril 233 receptov. Identifikačnými znakmi boli vek a pohlavie pacienta. Následne sa sledovala frekvencia výskytu diagnóz a spotreba liekov z rôznych hl'adísk, a to podl'a veku, pohlavia, zastúpenia jednotlivých diagnóz a podl'a ATC systému. Z výsledkov analýzy vyplynulo, že najčastejšími ochoreniami postihujúcimi deti a mládež sú ochorenia dýchacej sústavy, ochorenia ucha a hlávkového výbežku, tráviaceho traktu a ochorenia kože. Výskyt týchto ochorení bol až na ochorenia kože a podkožného tkaniva, približne rovnaký u obidvoch pohlaví. V súčasnosti je však ešte stále spotreba liekov, ktoré sú užívané det'mi a mládežou neustále vysoká, najmä v skupine detí od 7-15 rokov.

Acta Fac. Pharm. Univ. Comen., Suppl., 2012, VI, p. 44 - 51. 